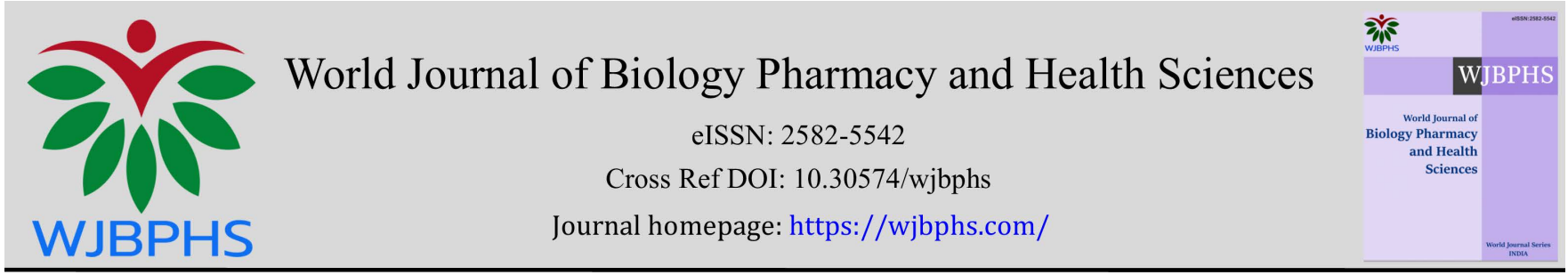

(RESEARCH ARTiCLE)

\title{
The effect of perceptions on the compliance with paying the National Health Insurance Contributions (NHI) of independent NHI participants during the covid-19 pandemic at the Langgikima community health center, Langgikima district, south Sulawesi province, 2021
}

\author{
Suhadi *, Eka Purnama Sari, Rahman and Jumakil \\ Department of Public Health, Faculty of Public Health, Halu Oleo University, Kendari, Indonesia.
}

World Journal of Biology Pharmacy and Health Sciences, 2022, 09(01), 054-060

Publication history: Received on 16 December 2021; revised on 24 January 2022; accepted on 26 January 2022

Article DOI: https://doi.org/10.30574/wjbphs.2022.9.1.0028

\begin{abstract}
National health insurance (NHI) as a universal health insurance program that applies to all Indonesian people without exception, with the implementing agency being the Social Security Administering Agency (SSA) which was established based on Law Number 24 of 2011 and declared to have started operating on January 1, 2014 and is expected to reach universal health coverage on January 1, 2019. The Covid-19 pandemic since 2020 has had a wide impact on society, one of which is the economic sector and the health service sector. The purpose of the study was to determine the effect of perceptions on compliance with paying SSA contributions independently in the work area of the Langgikima Health Center, North Konawe Regency. The type of research used is survey research with a Cross Sectional Study approach. This research was carried out in the working area of the Langgikima Public Health Center, North Konawe Regency, Southeast Sulawesi Province. The sample of this study was all independent NHI participants, namely 51 participants. Data Collection Using Questionnaires and Observations. Data analysis was carried out in univariate and bivariate ways. Presentation of data in the form of a frequency distribution table accompanied by an explanation. The results showed that there was no effect of perception on compliance with paying NHI contributions for independent NHI participants at Langgikima Health Center, with a p-value $=0.274$. The conclusion of the research is that there is no effect of perception on compliance with paying NHI contributions for independent NHI participants. The suggestions for this research are that it is hoped that the SSA needs to carry out socialization, education and information to independent NHI participants in order to better understand the NHI program such as the benefits of using the NHI program, procedures for paying NHI contributions, changing membership classes, paying NHI dues, and sanctions for arrears NHI.
\end{abstract}

Keywords: Perception; NHI Independent; Compliance; Contribution

\section{Introduction}

National Health Insurance is a new program in Indonesia in order to improve the health quality of its people. SSA is a legal entity established under the SSA Law to administer social security programs. Law Number 24 of 2011 concerning the Social Security Administering Body. Article 60 paragraph 1 of the SSA Law states that SSA Health will start operating on January 12014 . In Law Number 24 of 2011 it is also explained that the health social security administering body or known as SSA-health is a legal entity formed to administer social security programs and organize health care insurance for all Indonesian people [1]

Every Indonesian citizen must have awareness that NHI is made for every citizen where participation is mandatory with the principle of mutual cooperation. The principle of gotong royong can be realized in the form of a mutual cooperation

\footnotetext{
${ }^{*}$ Corresponding author: Suhadi

Department of Public Health, Faculty of Public Health, Halu Oleo University, Kendari, Indonesia.

Copyright (C) 2022 Author(s) retain the copyright of this article. This article is published under the terms of the Creative Commons Attribution Liscense 4.0.
} 
system from participants who are able to those who are less able, participants who have low risk help participants who have high risk and healthy participants help the sick. One of the mechanisms of gotong royong that can be realized is the mandatory participation of the NHI program for every color of the Indonesian state. Social security programs can foster social justice for all Indonesian people through the principle of mutual cooperation [2]

One of the biggest problems currently in the health sector is the ongoing outbreak of the Covid-19 disease that has hit all countries in the world, including Indonesia. Data from the Ministry of Health shows that entering 2021 the incidence of morbidity and mortality due to COVID-19 is still quite high. It was recorded that the morbidity rate had reached the highest number above 50 thousand cases in a day. This figure continues to decline until the end of 2021 until it declines to below 1000 cases per day. The decreasing number of cases of COVID-19 shows that the government's role in the Covid-19 vaccination service is getting better for the community.

The current reality is that independent membership registration continues to increase in the number of participants, but it is not in line with the participant's compliance to pay NHI contributions on a regular basis. It was recorded that since its launch on January 1, 2014, until October 2014, there were around 13,000 people (40\%) of all independent participants, not regularly paying NHI contributions. This has an impact on the availability of NHI funds where around Rp.3 Billion monthly dues are not paid on time. This is not proportional to the amount of contributions allocated by SSA Health to finance health services for sick participants, with a calculation of eleven times greater than the amount of income received by SSA for NHI premiums paid by participants.

Each health insurance program has its advantages and disadvantages. The advantages of SSA Health include premiums or payments that are quite cheap. Participants do not need to pay during the room class according to the premium taken. As long as you follow the procedure, all medical expenses will be borne by SSA. Meanwhile, the drawback of SSA is that the process is long and less flexible. Not all hospitals cooperate with SSA Health. Hospital costs that are not reimbursed, this is the condition that many SSA participants complain about [3]. Some of the shortcomings above cause public perception to be less good about SSA, so that not all people participate in the SSA program.

Perception is the ability of the brain in translating a stimulus or the process of translating a stimulus that enters the human senses. In human perception there are different points of view in sensing. There are those who perceive that something is good and positive, while there are negative perceptions that will affect visible or real human actions [4]. With the perception, individuals can realize and understand the state of the surrounding environment and the state of the individual concerned. So many people do not all have the same good perception about the use of health insurance that has been programmed by the government to get health services.

During the Covid-19 pandemic in early 2020, the government has made prevention efforts by implementing a largescale and small-scale lockdown program with the aim of overcoming the spread of the Covid-19 disease. Entering 2021, the disease prevention program will be more vigorously enforced by the implementation of restrictions on community activities to break the chain of transmission of COVID-19. The impact of the restrictions on community activities is the weakening of income in the economic sector, especially for the lower middle class who do not have a fixed income. Of course, this with reduced income or family income will have an impact on meeting primary needs, both food and drinks.

The impact of COVID-19 on health services is the delay in health services for a person due to arrears in payment of NHI contributions. The arrears in NHI contributions were caused by the reduced availability of income. One of the reasons for the low income is the limitation of community activities during the COVID-19 pandemic, where the opportunity to do business and get income funds is also reduced. Communities experiencing income difficulties will prioritize their income for food and beverage needs rather than the need for health services.

The number of SSA Health participants reached 155,189,547 people, consisting of 98,125,684 Contribution Assistance Recipients and 57,063,863 non-PBI Contribution Assistance participants. Of the total population of Indonesia $257,912,349$ people, it means that there are still around 102,722,802 people who have not been registered as SSA participants. SSA participants classified as non-PBI are PNS, TNI members, POLRI members, state officials, non-civil servant government employees, private employees. SSA in Indonesia is 2268 units and the number of SSA health participants is 195,170,283 million people [5]

Meanwhile in Southeast Sulawesi Province, the number of SSA Health participants reached 2,253,942 people. The number of independent SSA participants in Southeast Sulawesi reached 181,032 people [6]. The number of independent participants in North Konawe Regency until November 2020 is 182 people, which every month continues to decrease from all independent participants in North Konawe Regency. Data on the number of independent SSA participants at Langgikima Health Center were 51 participants with 11 active participants and 40 inactive participants. 


\section{Material and methods}

The type of research used is survey research with a Cross Sectional Study approach. This research was carried out in the working area of the Langgikima Public Health Center, North Konawe Regency, Southeast Sulawesi Province. The sample of this study was all independent NHI participants, namely 51 participants. Data Collection Using Questionnaires and Observations. Data analysis was carried out by Univariate and Bivariate. Presentation of data in the form of a frequency distribution table accompanied by an explanation [7].

\section{Results}

\subsection{Univariate Analysis}

\subsubsection{Perception}

Public perception of the NHI program is the response, attitude and action of the community towards the NHI program set by the government through the SSA Health Institution and health service units related to the independent participants' expectations for health services with the reality of the health services received. The perceptions of independent NHI participants are grouped into two categories, namely positive perceptions and negative perceptions. The distribution of respondents according to perceptions at the Langgikima Health Center, North Konawe Regency, is presented in table 1.

\begin{tabular}{|c|c|c|c|}
\hline No & Perception & Amount (n) & Percentage (\%) \\
\hline 1 & Negative & 34 & 66.7 \\
\hline 2 & Positive & 17 & 33.3 \\
\hline \multicolumn{2}{|c|}{ Totals } & 51 & 100 \\
\hline
\end{tabular}

Based on Table 1, it shows that out of 51 respondents (100\%), the number of respondents with negative perceptions was more, namely 34 respondents $(66.7 \%)$ than independent NHI participants with positive perceptions, namely 17 respondents $(33.3 \%)$.

\subsubsection{Obedience}

Compliance with paying NHI contributions is the willingness and obedience of independent NHI participants in making independent NHI contributions in accordance with the amount of contributions and the payment deadline set by the SSA Health. Compliance with paying dues is influenced by income, knowledge, level of education, behavior of someone who has the willingness and ability to pay dues in a timely manner based on a predetermined time. The distribution of respondents according to the level of compliance of independent participants in paying NHI premiums is grouped into two categories, namely compliant and non-compliant, as presented in table 2.

Table 2 Distribution of Respondents by Compliance with NHI Independent Participants in the Work Area of the Langgikima Health Center, Langgikima District, North Konawe Regency, Southeast Sulawesi Province in 2021

\begin{tabular}{|c|c|c|c|}
\hline No & Obedience & Amount (n) & Percentage (\%) \\
\hline 1 & Obey & 28 & 54.9 \\
\hline 2 & Not Obey & 23 & 45.1 \\
\hline \multicolumn{2}{|r|}{ Total } & 51 & 100 \\
\hline
\end{tabular}

Based on Table 2, it shows that out of 51 respondents (100\%), the number of independent NHI participants who comply with paying NHI contributions is 28 (54.9\%) compared to 23 (45.1\%) respondents who do not. 


\section{Bivariate Analysis}

\subsection{Effect of Perception on compliance with paying NHI Independent contributions}

Table 3 Relationship between Perception and Compliance of SSA Independent Participants in the Work Area of the Langgikima Health Center, Langgikima District, North Konawe Regency, Southeast Sulawesi Province in 2021

\begin{tabular}{|c|c|c|c|c|c|c|c|c|}
\hline \multirow{3}{*}{ No } & \multirow{3}{*}{ Perception } & \multicolumn{4}{|c|}{ Paying Compliance } & \multirow{2}{*}{\multicolumn{2}{|c|}{ Amount }} & \multirow{3}{*}{$\begin{array}{l}P \\
\text { Value }\end{array}$} \\
\hline & & \multicolumn{2}{|c|}{ Obey } & \multicolumn{2}{|c|}{ Not Obey } & & & \\
\hline & & $\mathbf{N}$ & $\%$ & $\mathbf{N}$ & $\%$ & $\mathbf{N}$ & $\%$ & \\
\hline 1. & Positive & 7 & 41.2 & 10 & 58.8 & 17 & 100 & \multirow[t]{3}{*}{0.274} \\
\hline 2. & Negative & 21 & 61.8 & 13 & 38.2 & 34 & 100 & \\
\hline \multicolumn{2}{|c|}{ Totals } & 28 & 54.9 & 23 & 45.1 & 51 & 100 & \\
\hline
\end{tabular}

Based on Table 3, it shows that of the 17 respondents (100\%) with positive perceptions, there are 7 respondents (41.2\%) who have compliance in paying NHI contributions and there are as many as 10 respondents (58.8\%) who do not have compliance with paying NHI contributions. Meanwhile, from 34 respondents (100\%) with negative perceptions, there are 21 respondents $(61.8 \%)$ who have compliance in paying NHI contributions and there are as many as 13 respondents (38.2\%) who do not have compliance with paying NHI contributions.

The results of the chi square test obtained $p$ value $=0.274(p>0.05)$ meaning Ho is accepted. This shows that there is no effect of perception on compliance with paying NHI contributions for independent NHI participants in the work area of the Langgikima Health Center, Langgikima District, North Konawe Regency, Southeast Sulawesi Province in 2021.

\section{Discussion}

Perception is part of an individual's assessment which is a characteristic of needs that allows for seeking treatment that can be manifested in action if it is felt as a need. In other words, the need is the basis and direct stimulus for using health services [8]. With the perception, individuals can realize and understand the state of the surrounding environment and the state of the individual concerned. So many people do not all have the same good perception about the use of health insurance that has been programmed by the government to get health services [9]

Public perception of health services that have collaborated with health insurance administering bodies can influence the public's desire to continue to pay National Health Insurance contributions regularly. An unpleasant first experience with health services received by the community will affect the formation of a person's perception of the need to extend his membership period and the regularity of the community in paying National Health Insurance contributions. On the other hand, health insurance participants who have a positive perception of health care facilities will increase their regularity in paying health insurance contributions because participants have received good service and experience when receiving health services so that it will increase the continuity of the health fund participation [10].

Currently, during the Covid-19 period, restrictions on community activities for work will have an impact on people's income and income for residents who do not have a fixed income. This will make it difficult for the community to meet the needs of life, including health services. Independent NHI participants have an obligation to pay SSA contributions every month as a consequence of being a NHI participant. If participants do not pay the NHI dues, they will receive sanctions in the form of fines, the elimination of membership and not receiving NHI health services.

The results of Rismawati's research in 2017 which states that there is a significant relationship between NHI perceptions and compliance with paying SSA independent contributions [11]. People who have a positive perception of health care facilities that have cooperation with the insurance they follow will have awareness in regularly paying health insurance contributions because they have had experience in receiving good services from health care providers. Thus, there is a need for coordination between health care providers and the insurance company to create a positive perception so that there is regularity in the payment of health insurance/insurance contributions.

Based on the research findings in table 1, it shows that, in general, independent NHI participants who expressed negative perceptions, were more numerous than independent NHI participants who expressed positive perceptions. This shows that the higher the negative perception, the higher the non-compliance in paying NHI contributions. 
Conversely, the lower the negative perception, the lower the non-compliance in paying NHI contributions. This happens because independent NHI participants are aware of their wants and needs for health services. If the health services needed and desired are in accordance with the value of the benefits and exceed their wishes, the independent NHI participant will continue to strive to remain obedient in paying the NHI fees, but on the contrary if the health services needed and desired are not in accordance with the value of the benefits and do not exceed their wishes, the NHI participant is independent. become disobedient to pay NHI fees. However, sometimes independent NHI participants will comply with the payment of NHI dues if they continue to need NHI services, and when they have recovered from illness, sometimes they are in arrears or do not pay NHI dues because they think they have not experienced the current illness. Likewise, during the current Covid-19 pandemic, some independent NHI participants are reluctant to pay NHI dues due to reduced income due to the government's restrictions on working outside the home, so this has an impact on family income. Conditions like this, in their perception that during the Covid-19 pandemic, with reduced income, they will prioritize meeting the needs of eating, drinking, and clothing as their main needs rather than providing the cost of paying NHI contributions.

Conceptually, several factors that influence compliance in paying NHI contributions include aspects of knowledge, level of education, employment factor, availability of service facilities, access and distance to services, factors of ability and willingness to pay contributions, aspects of perception of health services, income, confidence. and motivational aspects. The results of the study [12] that education affects the perception of risk, the degree of risk aversion and the perception of the magnitude of the loss. The higher the level of education, the more knowledge about health insurance information and the need for health services. When someone has a higher education level, they can better understand and know the benefits and needs that are considered important, such as the need for health services that can be guaranteed by paying health insurance contributions so that the level of a person's desire to pay these contributions will increase, and vice versa if someone has a high level of education. Low education can reduce their desire to pay health insurance contributions because the level of understanding and knowledge about the existence of health insurance contributions is still low.

From the results of the study, it was found that, in general, independent NHI participants who expressed negative perceptions, more in number than independent NHI participants expressed positive perceptions. This is because independent NHI participants want health services that are easily accessible, quality health services, affordable NHI fees adjusted to the ability of the community, easy places to pay NHI contributions, and the elimination of NHI dues fines.

The public's perception of health services that have collaborated with health insurance administering bodies can influence the public's desire to continue to pay National Health Insurance contributions on a regular basis. An unpleasant first experience with health services received by the community will affect the formation of a person's perception of the need to extend his membership period and the regularity of the community in paying National Health Insurance contributions. On the other hand, health insurance participants who have a positive perception of health care facilities will increase their regularity in paying health insurance contributions because participants have received good service and experience when receiving health services so that it will increase the sustainability of the health fund participation [13].

The results showed that of the 17 respondents (100\%) who had a positive perception, there were 7 respondents $(41.2 \%)$ who complied with paying the independent NHI dues, this happened because the independent NHI participants realized that health was very important and supported life, so it must be maintained. In addition, by paying independent NHI contributions, they can already get protection from the risk of getting sick, especially those requiring inpatient care and expensive medical procedures. Meanwhile, of the 34 respondents (100\%) who have negative perceptions, there are 13 respondents (38.2\%) who do not have compliance with paying NHI contributions, this is because they feel burdened with their finances during the current covid-19 pandemic as well as the benefits of health services. It has not been felt at this time because they have not experienced illness, so independent NHI participants feel that it is futile to pay their monthly NHI dues. Some patients complain that NHI contributions have increased so that independent NHI participants feel a heavy burden from the increase in fees. Meanwhile, 21 respondents (61.8\%) had a negative perception but obeyed the payment of NHI contributions, this happened because they had experienced disappointment with the health services they received, although they were disappointed but still continued to pay premiums because there were fears and worries in the future they would have pain.

The results of this study prove that the perception of independent NHI participants in Langgikima District on compliance with paying NHI contributions is generally categorized as non-compliant, this is because they feel in good health so there is no need to pay independent NHI contributions. to get health services. In this condition they will be faced with rejection of health services by the health facilities because there are arrears in NHI contributions. 
Perceptions formed from the first experience of health care facilities that have collaborated with SSA Health can influence the desire to continue to pay SSA Health contributions obediently. An unpleasant first experience received in health services will affect the formation of perceptions of the need to extend the period of membership and compliance in paying NHI Independent contributions [14]. This finding is in line with this study, which states that the positive perception felt by independent NHI participants will have an impact on compliance with paying NHI contributions.

The results of the chi square test obtained a value of $p=0.274(p>0.05)$ meaning Ho is accepted. This shows that there is no effect of the perception of independent NHI participants on compliance with paying independent NHI contributions in the work area of the Langgikima Health Center, North Konawe Regency in 2021. The results of this study are in line with research conducted by [15] [16] which said that there was no significant relationship There is a significant relationship between perception and compliance with paying NHI Independent contributions. However, the results of this study are not in line with the results of studies [14], [17], [18], [19], [20], [21], [22], [23] which say that perception affects compliance in paying NHI contributions.

From the statistical test results, it was found that there was no effect of the perception of independent NHI participants on compliance with paying independent NHI contributions in the work area of the Langgikima Health Center, North Konawe Regency in 2021, this happened because there were several other factors that also influenced the compliance of independent NHI participants in paying NHI contributions, namely factors of the quality of the services they receive, the level of income during the current Covid-19 pandemic, their beliefs, level of education, number of dependents, the distance from where they live to where they pay NHI contributions, and the role of SSA officers in motivating independent NHI participants.

\section{Conclusion}

The conclusion of this study is that there is no effect of perception on compliance with paying NHI contributions for independent participants in the work area of the Langgikima Health Center, North Konawe Regency, Southeast Sulawesi Province in 2021 with a $\mathrm{p}$ Value $=0.274$. The research suggestion is that it is hoped that the SSA needs to carry out socialization, education and information to independent NHI participants to better understand the NHI program such as the benefits of using the NHI program, procedures for paying NHI contributions, changing membership classes, paying NHI dues, and sanctions for arrears in NHI contributions.

\section{Compliance with ethical standards}

\section{Acknowledgments}

The author would like to thank the Dean of the Faculty of Public Health, Halu Oleo University, who has provided support to the writing team so that this research can be carried out properly. Furthermore, the team of authors would like to thank all those who have helped until the end of this research.

\section{Disclosure of conflict of interest}

All authors state that this research was conducted without any conflict of interest.

\section{Statement of informed consent}

All informants/respondents involved in this study have stated their consent as informants/respondents to be interviewed and provided information/information in accordance with research needs.

\section{Author contribution}

Suhadi, Eka Purnama Sari, and Rahman as designers, implementers of research and drafts of Reports. Jumakil as the reviewer of the Lapora manuscript. Eka Purnama Sari as data collector, analyze and interpreter of data. All authors read and agree to the Final Report.

\section{References}

[1] Presidential, RI. Law of the Republic of Indonesia Number 24 of 2011 concerning Social Security Administering Bodies. 2011; 1-68. 
[2] Health Ministry RI, Indonesian Health Profile. Indonesian Health Ministry. 2014.

[3] Dewi, MW. D Sulistyani. Comparison of Health Insurance Premiums for Business Entity SSAB Participants with Private Health Insurance, Accounting and Tax, J. 2017; 16(01).

[4] Donsu, Nursing Psychology. Jogjakarta: New Press Library. 2017.

[5] Darmawansyah, D. MY Abadi, S Rahmadani, DS Marzuki, R Suryaman. Determination of Rational Tariffs for Health Services at Tenriawaru Hospital, Bone Regency, Indonesian Public Health Media. 2018; 14(2): 165.

[6] SSAB, Health Social Security Administering Body Profile Year. 2020; 01, no. 04. 2020, pp. 382-393.

[7] Sugiyono, Quantitative and Qualitative Research Methodology. Bandung: Alfabeta. 2015.

[8] Hasyim, HM Idrus, S Rizky. Factors Related to Work Arrears At The Abeli Public Health Center In Kendari, Miracle J. Of Public Health. 2019; 2(1): 1-9.

[9] Sugihartono, Educational Psychology. Jogjakarta: UNY Press. 2017.

[10] Widyanti N. Factors Relating to Compliance with Paying Independent National Health Insurance Contributions to Patients at the Labuang Baji Regional General Hospital, Makassar City, Thesis. 2018; 129.

[11] Rismawati, Lisnawaty NN Jufri. Factors Relating to the Decision to Pay Independent National Health Insurance Contributions in the Work Area of the Batalaiworu Health Center, Batalaiworu District, Muna Regency. Public Health Student Scientific, J. 2017; 2(8): 1-10.

[12] Handayani, Gondodiputro, Saefullah. Factors Affecting Community Willingness to Pay Health Insurance Contributions in Hulu Sungai Selatan District, University Padjadjaran Bandung. 2013.

[13] Fauziyyah I. Analysis of Ability to Pay and Willingness to Pay PBPU Participants who are in arrears in Health Insurance Contributions in Tamalate District, Makassar City, J. Health Management of the Dr. Hospital Foundation. Soetomo. 2016; 5(2): 102.

[14] Ahmad M, N Muchlis, Haeruddin. Study Of Non-Compliance Of Paying Independent's National Health Security Contributions In Tamalanrea, Makassar City, Window. Public Health. J. 2021; 01(05): 502-511.

[15] Latifah N, W Nabila, F Fajrini. Factors Affecting Compliance Independent Participants, J, of Medicine and Health. 2020; 16(2): 84-92.

[16] Pratiwi AN. Factors Affecting The Regularity Of Paying Contributions To National Health Insurance Participants Category Of investa dana dollar Independent. University of jember. 2016.

[17] Hasan N, AS Batara. Factors Related To Compliance With Paying The National Health Security Contributions In Independent Participants At The Tamamaung Community Health Center, Window. Public Heal. J. 2020; 01(04): 382-393.

[18] Rismawati, Lisnawaty, NN Jufri. Factors Related With Compliance Paying Of SSAB Independent Insurance/ Contribution In The Working Area Of Batalaiworu Public Health Center In 2017, Scientific Health, J. 2017; 2(8): $1-10$.

[19] Ramadani AN, Haeruddin, AS Batara. Factors Related To Compliance With Paying The National Health Security Contributions In Independent Participants In Bontomatene District, Window. Public Health, J. 2021; 01(06): 609619.

[20] Wulandari A, NA Syah, T Ernawati. Factors Affecting the Compliance of Independent Participants in Payment of Contributions for the National Health Insurance Program in Solok City, J. Health. Andalas. 2020; $9(1): 7$.

[21] IGGOP dan IMP Astakoni. Awareness, Knowledge And Understanding And Perceptions Of Taxpayers As Determinants Of Tax Willing to pay tax. J, Krisna. 2018; 10(1): 1-10.

[22] Pangesti DM, AN Yushita. The Effect of Awareness of Paying Taxes, Perceptions of the Effectiveness of the Taxation System, and Understanding of Government Regulation Number 23 of 2018 on Willingness to Pay Taxes. J, of Accounting and Management. 2019; 8(2): 166-178.

[23] Nugroho IH, A Dewi, I Nazaruddin. Analysis of Factors Affecting Willingness to Pay National Health Insurance for Informal Workers in Kulonprogo," J. Health management. Hospital Foundation Dr. Soetomo. 2021; 7(1): 59. 